\title{
EFFECT OF AGRICULTURAL AND NON-AGRICULTURAL EXPORTS ON ECONOMIC GROWTH IN IVORY COAST
}

\author{
Paul-Alfred Kouakou KOUAKOU
}

\author{
Address: \\ Peleforo Gon COULIBALY University, Agrarian Management Institute, Korhogo, Ivory Coast \\ E-mail: drkouakou@ rocketmail.com
}

\begin{abstract}
The objective of this paper is to assess, empirically, the effects of agricultural and non-agricultural exports on economic growth in Ivory Coast. The data used are those of the World Bank (World Development Indicators) and the Central Bank of West African States and cover the period from 1985 to 2015. The analysis of the data required the use of the AutoRegressive Distributed Lag (ARDL). It emerges from the study that the agricultural exports have positive and significant effects on the Gross Domestic Product. However, this rate appears to be increasingly weak in long term. On the other hand, the non-agricultural exports have a positive but not significant effect on economic growth in short term. Nevertheless, in the long run, they improve the country's economic performance. Moreover, the Gross Fixed Capital Formation stimulates the economic wealth generation. Finally, the trade openness negatively affects the economic development. Therefore, the Ivorian government, while giving priority to improving the competitiveness of export products, must apply a diversification policy in order to reduce the risks of deterioration in the terms of trade.
\end{abstract}

Keywords: Exports; Economic growth; Ivory Coast

JEL: C01; O47; Q00

\section{INTRODUCTION}

Ivory Coast, an exporter of primary products, is heavily dependent on agriculture in the formation of its wealth. Indeed, agriculture contributes to $22.3 \%$ of GDP and accounts for $47 \%$ of the country's overall exports $(62 \%$ excluding oil). It employs $46 \%$ of the country's working population and is an important source of income for two thirds of the Ivorian population according to Banque Mondiale (2016).

However, dependence on world prices of agricultural raw materials plunged the country into a deep crisis from 1980 to 1993 . This crisis was characterized by a sharp drop in economic growth, a significant drop in per capita income, worsening internal and external imbalances (deterioration of the balance of payments, growing public deficits) according to AISA (2015). This underperformance of the agricultural sector, which makes a significant contribution to national GDP, can be explained by the low level of agricultural productivity, the slump in production, the low purchase prices of agricultural products and an inequitable distribution of the rebates generated by the various sectors. In addition to these causes, there are significant post-harvest losses, the low level of conservation and processing of agricultural products, the general ageing of orchards, insufficient use of quality inputs and the poor mastery of modern cultivation techniques. Moreover, the cost of inputs remains high and research results are not always accessible and sufficiently valued. Similarly, agricultural actors are insufficiently supervised and have limited access to credit and to regional and international markets (Kouakou, 2017). Finally, the agricultural sector suffers from the isolation of many production areas. In addition, the industrial processing of agricultural production remains insufficient to drive strong economic growth, substantially improve added value and absorb local production (AISA, 2015).

To cope with this situation, Ivory Coast has been engaged since 1994 in a process of diversification of its economy under the aegis of the Bretton Woods institutions, including the IMF and the World Bank. Today, export production accounts for nearly $40 \%$ of export earnings and supports the country's agro-industrial development. These exports are also dominated by agricultural products (about $60 \%$ ) and non-agricultural products (about $40 \%$ ) according to Zamble (2015).

However, despite these achievements and according to AISA (2015), diversification has not yet had a significant effect. Competition and international legislation constitute a hindrance to the development of other sectors of the economy. Moreover, world economies are marked by vulnerability to the dynamics of external trade. In this context, it is necessary to assess the contribution of agricultural and non-agricultural exports to Ivory Coast's economic growth. Specifically, it is necessary to estimate the causal link between agricultural and non-agricultural exports and economic growth in Ivory Coast.

\section{DATA AND METHODS}

\section{Theoretical and conceptual frameworks}

Several studies have been carried out by economists to show the relationship between economic growth and exports. 
Michaely (1977) tested the hypothesis that rapid export growth accelerates a country's economic growth. He examined Spearman's rank correlation coefficient between the growth rates of two series that represent, respectively, the average size of annual changes in the ratio of exports to GNP and the average annual change in the ratio of GNP per capita. He concludes that for a number of countries in his sample, this correlation is significant. Balassa (1978), following Michaely's lead, also uses Spearman's rank correlation coefficient to test the correlation that might exist between different export and economic growth ratios for a group of developing countries over the 1960-73 period. He concludes that the addition of exports to the explanatory variables, on the GNP side, increases the overall significance of the model. In addition, the coefficient on exports is found to be statistically significant. Feder (1983) notes that the contribution of exports to GDP growth exceeds the simple change in its volume. He constructs two production functions, one for the export sector, and other for the domestic sector. Feder's regression results cover the period 1964-1973 for a sample of 31 countries, 19 of which are defined as semi-industrialized and 22 marginally semi-industrialized. The conclusion of its results asserts that there is a substantial productivity gap between exports and non-exports in addition to the differential due to externalities.

Similarly, Jlidi (1996), in his study on exports, imports and economic growth, shows, after decomposing total exports into manufacturing exports on the one hand and raw materials on the other, that the first type of exports (manufacturing products) generates more externalities than the second. One of the probable explanations for the difference between the externalities generated by each type of export may be the fierce competition on the world market for finished goods. It concludes that the long-term growth of developing countries depends largely on the stability and performance of their export sectors (manufacturing and intermediate inputs) in favourable global conditions. N'Zue (2003) has carefully studied the Granger causal relationship between export expansion and economic growth in Ivory Coast and finds its effects on employment creation. He indicates that although there is no cointegration between exports and economic growth, there is a circular relationship between them. Kpemoua (2016), empirically, analysed the impact of exports on economic growth in Togo as well as the existence of a causal relationship between exports and economic growth by applying a model based on a neoclassical production function. The data cover the period 1960-2014. The methodological approach used is based on cointegration and causality techniques. The empirical results show a positive and significant correlation at the threshold of $1 \%$ in the long term between exports and economic growth and a causality in the sense of Toda and Yamamoto, of exports to economic growth. According to all these previous studies, exports are an important source of economic growth.

\section{Data collection}

The data relating to the variables: Gross Domestic Product per Capita (GDP), Gross Fixed Capital Formation (GFCF) and trade openness (OC) were calculated from data taken from the World Development Indicators (World Bank), while agricultural exports (XA) and non-agricultural exports (XNA) were taken from the database of the Central Bank of West African States. The study covers the period from 1985 to 2015 . The choice of this study period is necessary in order to avoid series with missing data. All model variables are in natural logarithms (Appendix 1).

\section{Method of analysis}

The analysis is based on the neoclassical growth model originally developed by Solow in 1956. This neoclassical production function is specified in terms of traditional inputs such as labour $(\mathrm{L})$ and capital $(\mathrm{K})$ and is written (Eq. 1):

$$
\mathrm{Y}=\mathrm{F}(\mathrm{K}, \mathrm{L})
$$

Taking into account the specificity of the present study, the ARDL model of Pesaran et al. (2001) was used.

The ARDL (AutoRegressive Distributed Lag) model is one of the time-shift models. The use of this model is justified by the fact that it takes into account both the short-term and long-term relationships of the variables tested. The advantage of the ARDL method, in contrast to the latter, can be found at two levels. On the one hand, it can be applied to any degree of integration of the variables used: pure I (0), pure I (1) or mixed. On the other hand, it has superior statistical properties for small samples. To do this, the ARDL model used is as follows (Eq. 2).

$\mathrm{GDP}=\mathrm{f}(\mathrm{GFCF}, \mathrm{XA}, \mathrm{XNA}, \mathrm{CO})$

The long-term equation can be written as follows (Eq. 3):

$$
\begin{aligned}
& \mathrm{LGDP}_{\mathrm{t}}=\alpha_{0}+\emptyset \sum_{\mathrm{i}=1}^{\mathrm{p}} \mathrm{LGDP}_{\mathrm{t}-\mathrm{i}}+\alpha_{1} \sum_{\mathrm{i}=0}^{\mathrm{q}} \mathrm{LGFCF}_{\mathrm{t}-\mathrm{i}}+ \\
& \alpha_{2} \sum_{\mathrm{i}=0}^{\mathrm{q}} \mathrm{LXA}_{\mathrm{t}-\mathrm{i}}+\alpha_{3} \sum_{\mathrm{i}=0}^{\mathrm{q}} \mathrm{LXNA}_{\mathrm{t}-\mathrm{i}}+\alpha_{4} \sum_{\mathrm{i}=0}^{\mathrm{q}} \mathrm{LCO}_{\mathrm{t}-\mathrm{i}}+ \\
& \varepsilon_{\mathrm{t}}
\end{aligned}
$$

The equation for the cointegrating relationship is obtained from the following error correction model (Eq. 4):

$$
\begin{aligned}
& \Delta \mathrm{LGDP}_{\mathrm{t}} \quad=\quad \alpha_{0}+\emptyset_{1 \mathrm{j}} \sum_{\mathrm{i}=1}^{\mathrm{p}} \Delta \mathrm{LGDP}_{\mathrm{t}-\mathrm{i}}+ \\
& \alpha_{1 \mathrm{i}} \sum_{\mathrm{i}=0}^{\mathrm{q}} \Delta \mathrm{LGFCF}_{\mathrm{t}-\mathrm{i}}+\alpha_{2 \mathrm{i}} \sum_{\mathrm{i}=0}^{\mathrm{q}} \Delta \mathrm{LXA}_{\mathrm{t}-\mathrm{i}}+ \\
& \alpha_{3 \mathrm{i}} \sum_{\mathrm{i}=0}^{\mathrm{q}} \Delta \mathrm{LXNA}_{\mathrm{t}-\mathrm{i}}+\alpha_{4 \mathrm{i}} \sum_{\mathrm{i}=0}^{\mathrm{q}} \Delta \mathrm{LCO}_{\mathrm{t}-\mathrm{i}}+\lambda \mathrm{ECM}_{\mathrm{t}-\mathrm{i}}+\varepsilon_{\mathrm{t}}
\end{aligned}
$$

With $E C M_{t-1}$, the error correction term (Eq. 5) $\mathrm{ECM}_{\mathrm{t}-1}=\mathrm{LGDP}_{\mathrm{t}}-\alpha_{0}-\emptyset \sum_{\mathrm{i}=1}^{\mathrm{p}} \operatorname{LGDP}_{\mathrm{t}-\mathrm{i}}-$ $\alpha_{1} \sum_{\mathrm{i}=0}^{\mathrm{q}} \mathrm{LGFCF}_{\mathrm{t}-\mathrm{i}}-\alpha_{2} \sum_{\mathrm{i}=0}^{\mathrm{q}} \mathrm{LXA}_{\mathrm{t}-\mathrm{i}}-\alpha_{3} \sum_{\mathrm{i}=0}^{\mathrm{q}} \mathrm{LXNA}_{\mathrm{t}-\mathrm{i}}-$ $\alpha_{4} \sum_{\mathrm{i}=0}^{\mathrm{q}} \mathrm{LCO}_{\mathrm{t}-\mathrm{i}}$

Taking into account the short and long-term effects, the ARDL representation is as follows (Eq. 6): 
Table 1: Variables used

\begin{tabular}{llc}
\hline Variables & Descriptions & Expected effect \\
\hline GDP & Gross Domestic Product per capita expressed in US Dollar & \\
GFCF & Gross fixed capital formation: this variable is a "proxy" for the investment & + \\
XA & Agricultural exports expressed in volume & + \\
XNA & Non-agricultural exports expressed in volume & + \\
CO & Commercial opening expressed in US Dollars ((Import + Export)/GDP) & + \\
\hline
\end{tabular}

Source: Author (based on theory)

$\Delta \mathrm{LGDP}_{\mathrm{t}}=\alpha_{0}+\alpha_{1} \sum_{\mathrm{i}=1}^{\mathrm{p}} \Delta \mathrm{LGDP}_{\mathrm{t}-\mathrm{i}}+\alpha_{2} \sum_{\mathrm{i}=0}^{\mathrm{q}} \Delta \mathrm{LXA}_{\mathrm{t}-\mathrm{i}}+$ $\alpha_{3} \sum_{\mathrm{i}=0}^{\mathrm{q}} \Delta \mathrm{LXNA}_{\mathrm{t}-\mathrm{i}}+\alpha_{4} \sum_{\mathrm{i}=0}^{\mathrm{q}} \Delta \mathrm{LCO}_{\mathrm{t}-\mathrm{i}}+\beta_{1} \mathrm{LGDP}_{\mathrm{t}-1}+$

$\beta_{2} \mathrm{LXA}_{\mathrm{t}-1}+\beta_{3} \mathrm{LXNA}_{\mathrm{t}-1}+\beta_{4} \Delta \mathrm{LCO}_{\mathrm{t}-1}+\varepsilon_{\mathrm{t}}$

Where:

$\Delta$ first difference operator;

$\alpha_{0}$ a constant;

$\alpha_{1} \ldots . \alpha_{4}$ short-term coefficients;

$\beta_{1} \ldots . \beta_{4}$ long-term coefficients;

$\varepsilon_{\mathrm{t}} \sim \operatorname{iid}(0, \sigma)$ an error term (white noise);

$\lambda$ the restoring force towards balance.

Table 1 presents the variables of the study.

\section{RESULTS AND DISCUSSION}

\section{Economic growth trends in Ivory Coast}

According to Figure 1, the period from 1985 to 2015 is marked by varying degrees of fluctuation in the annual growth rate. Indeed, the first decades of the country's independence were marked by a period of strong growth justified by the coffee and cocoa boom. However, from 1985 onwards, Ivory Coast experienced a severe economic crisis due to the fall in the prices of these main export products on the international market. This weakened its economy until 1990.

From 1990 onwards, the structural adjustment programme imposed by the Bretton Woods structures, including the International Monetary Fund, began to take effect, leading to a slight recovery until 1998, when the country fell into a military crisis and economic decline resumed.

From 2000 onwards, the economy rebounded again due to a noticeable stability but was quickly slowed down from 2002 onwards by a socio-political crisis. From 2002 to 2005 , peace agreements were signed and the economy recovered slightly.

From 2005 to 2010, the Ivorian economy returns to positive growth rates. However, from 2010 to 2011, Ivory Coast experiences a severe post-electoral crisis. This weakened all economic activities. Moreover, it is the most severe crisis that this country has experienced because the growth rate was negative $(-5 \%)$.

From 2011 to 2015 , the economy recovered to achieve the marvellous performance of the double-digit growth rate (over 10\%) and remained somewhat stable, before declining slightly and stabilizing at $8 \%$ from 2015 onwards.

\section{Agricultural and non-agricultural exports trends in Ivory Coast}

From 1985 to 2010, Ivory Coast gradually increased its export volume of agricultural products, reaching a peak in 1990 according to Figure 2. From 2010 to 2014, agricultural exports remained stable. However, the period 2015 is marked by a drop in export volumes due to the effect of climate change, which causes seasonal variations and the appearance of devastating caterpillars. According to this same figure, exports of non-agricultural products increased over time. However, this increase was strong from 1994 onwards because of the policy of diversification of export products implemented by the Ivorian government under the Structural Adjustment Programme.

\section{Descriptive characteristics of the variables}

Table 2 shows that variables such as non-agricultural exports and trade openness are more volatile compared to other variables. Moreover, the variables in the study follow a normal distribution law (Prob > 5\%).

Variables such as gross domestic product, gross fixed capital formation, non-agricultural export and trade openness are all stationary in first difference and are included in first order, while the variable such as agricultural export remains stationary at the level (Table 3 ). The series are thus integrated at different orders. This renders Engle's and Granger's cointegration test (multivariate case), as well as Johansen's, ineffective, but makes the cointegration test at the bounds of Pesaran et al. (2001) appropriate.

Variables such as gross domestic product, gross fixed capital formation, non-agricultural export and trade openness are all stationary in first difference and are included in first order, while the variable such as agricultural export remains stationary at the level (Table 3 ). The series are thus integrated at different orders. This renders Engle's and Granger's cointegration test (multivariate case), as well as Johansen's, ineffective, but makes the cointegration test at the bounds of Pesaran et al. (2001) appropriate.

With regard to Table 4, the optimal delay number of the ARDL model is 4, as the AIC and SC information criteria are at their minimum value. Moreover, this makes it possible to estimate the ARDL model. 


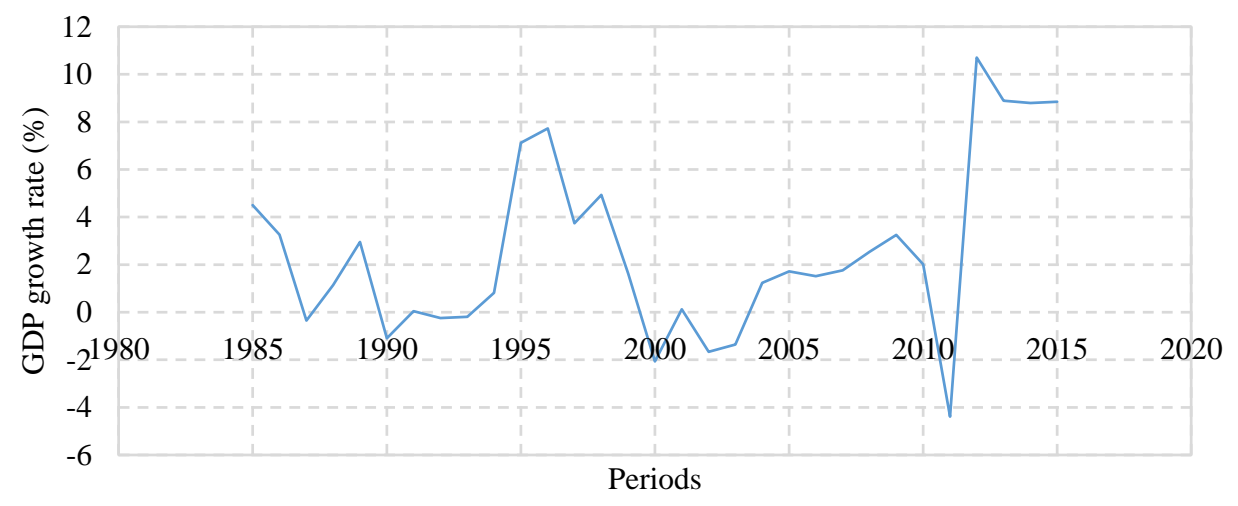

Figure 1: Change in annual GDP growth rate from 1985 to 2015, (\%) Source: Author, estimation using Eviews software.

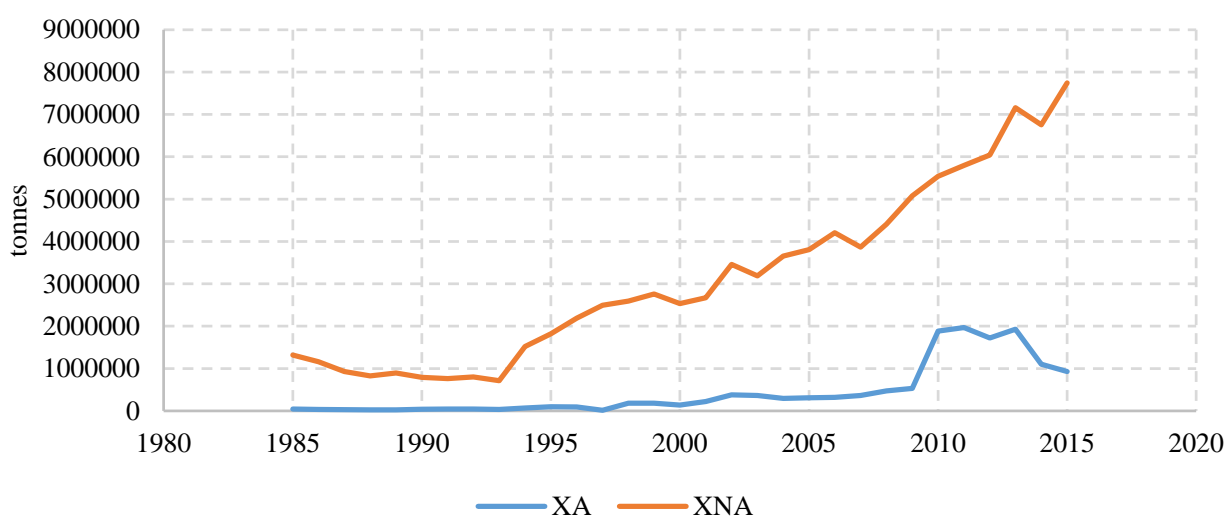

Figure 2: Evolution of agricultural and non-agricultural exports in tonnes over the period 1985-2015 Source: Author, estimation using Eviews software.

Table 2: Descriptive analysis of the variables used

\begin{tabular}{lllrrr}
\hline & LGDP & LGFCF & \multicolumn{1}{l}{ LCO } & \multicolumn{1}{c}{ LXA } & \multicolumn{1}{l}{ LXNA } \\
\hline Mean & 7.199415 & 2.430310 & 16.29572 & 12.06866 & 14.70933 \\
Median & 7.180922 & 2.441029 & 16.33933 & 12.12087 & 14.79737 \\
Maximum & 7.402426 & 2.971941 & 16,80513 & 14.49250 & 15.86215 \\
Minimum & 7.037612 & 2.110633 & 15.71302 & 9.598863 & 13.47756 \\
Std.Dev. & 0.096132 & 0.233446 & 0.361728 & 1.478349 & 0.763264 \\
Skewness & 0.512859 & 0.641897 & -0.272761 & 0.125854 & -0.260177 \\
Kurtosis & 2.387816 & 2.749632 & 1.691272 & 1.865136 & 1.780027 \\
Jarque-Bera & 1.843038 & 2.209797 & 2.596719 & 1.745394 & 2.272174 \\
Probability & 0.397914 & 0.331244 & 0.272979 & 0.417823 & 0.321073 \\
Sum & 223.1819 & 75.33960 & 505.1672 & 374.1283 & 455.9892 \\
Sum Sq. Dev. & 0.277239 & 1.634914 & 3.925406 & 65.56550 & 17.47716 \\
Observations & 31 & 31 & 31 & 31 & 31 \\
\hline Source: Author, estimation using Eviews software. & &
\end{tabular}

Source: Author, estimation using Eviews software. 
Table 3: Results of stationarity tests (ADF \& PP)

\begin{tabular}{lrrrrr}
\hline VARIABLES & LEVEL & \multicolumn{5}{c}{ DIFFERENCE 1rst } & STATEMENT \\
& ADF & \multicolumn{1}{c}{ PP } & \multicolumn{1}{c}{ ADF } & \multicolumn{1}{c}{ PP } & \\
\hline LGDP & -0.83 & -0.21 & -3.61 & -3.62 & $\mathrm{I}(1)$ \\
& $(0.95)$ & $(0.98)$ & $(0.04)^{*}$ & $(0.04)^{*}$ & \\
LGFCF & -1.45 & -1.67 & -4.96 & -4.95 & $\mathrm{I}(1)$ \\
& $(0.82)$ & $(0.73)$ & $(0.00)^{*}$ & $(0.00)^{*}$ & \\
LXA & -4.50 & -4.47 & - & - & $\mathrm{I}(0)$ \\
& $(0.00)^{*}$ & $(0.00)^{*}$ & & & \\
LXNA & 1.83 & -3.03 & -4.61 & -5.12 & $\mathrm{I}(1)$ \\
& $(0.98)$ & $(0.13)$ & $(0.00)^{*}$ & $(0.00)^{*}$ & \\
LCO & -0.78 & -1.24 & -4.62 & -4.60 & $\mathrm{I}(1)$ \\
& $(0.95)$ & $(0.88)$ & $(0.00)^{*}$ & $(0.00)^{*}$ & \\
\hline
\end{tabular}

Note: * indicates that these tests are significant respectively at the $5 \%$ threshold;

(.) the values in brackets are the different probabilities

Source: Author, estimation using Eviews software.

Table 4: Results of delay number determination

\begin{tabular}{lrr}
\hline Delay & AIC & SC \\
\hline 0 & -2.17 & -1.93 \\
1 & -7.71 & -6.27 \\
2 & -7.74 & -5.10 \\
3 & -9.30 & -5.46 \\
4 & $-11.68^{*}$ & $-6.64^{*}$ \\
\hline
\end{tabular}

Note: * indication of the order of the criterion

Source: Author, estimation using Eviews software.

Table 5: ARDL model $(1,2,0,3,2)$

Dependent Variable: LGDP

Method: ARDL

Sample (adjusted): 19882015

Included observations: 28 after adjustments

Maximum dependent lags: 1 (Automatic selection)

Model selection method: Akaike info criterion (AIC)

Dynamic regressors (4 lags, automatic): LGFCF LXA LXNA LCO

Selected Model: ARDL $(1,2,0,3,2)$

\begin{tabular}{lrrrr}
\hline Variables & Coefficient & Std. Error & \multicolumn{1}{c}{ t-statistic } & \multicolumn{1}{c}{ Prob.* } \\
\hline LGDP(-1) & 0.289764 & 0.157772 & 1.836599 & 0.0862 \\
LGFCF & 0.159022 & 0.020089 & 7.915872 & 0.0000 \\
LGFCF(-1) & -0.045540 & 0.032219 & -1.413457 & 0.1779 \\
LGFCF(-2) & 0.075389 & 0.025384 & 2.969919 & 0.0095 \\
LXA & -0.009184 & 0.005014 & -1.831612 & 0.0869 \\
LXNA & 0.002586 & 0.035314 & 0.073219 & 0.9426 \\
LXNA(-1) & -0.001905 & 0.039108 & -0.048706 & 0.9618 \\
LXNA(-2) & 0.075899 & 0.034811 & 2.180325 & 0.0456 \\
LXNA(-3) & 0.039018 & 0.020032 & 1.947805 & 0.0704 \\
LCO & $-0,142075$ & 0.068777 & -2.065719 & 0.0566 \\
LCO(-1) & 0.091950 & 0.086697 & 1.060591 & 0.3057 \\
LCO(-2) & -0.258159 & 0.085926 & -3.004438 & 0.0089 \\
C & 8.091700 & 1.830391 & 4.420750 & 0.0005 \\
R & 0.973046 & Mean of the variable & 7.179543 \\
R ${ }^{2}$ Adjusted & 0.951484 & & & \\
Akaike Criteria & -5.001424 & & & \\
Schwarz Criterion & -4.382901 & & & \\
Stat of Fisher & 45.12602 & & & \\
Fisher's Probability & 0.000000 & & & \\
\hline Source: Author, estimation using Eviews & $50 f w a r$ & & &
\end{tabular}

Source: Author, estimation using Eviews software. 
Estimation of the ARDL model. The coefficient of determination $\left(\mathrm{R}^{2}\right)$ is 0.973046 . This implies that $97.30 \%$ of the variation in Gross Domestic Product is explained by the independent variables (Table 6). The value of the coefficient of the restoring force is between 0 and 1 in absolute value. The statistical difference between the variables is eliminated at $71.02 \%$ in the study period.

The ARDL model $(1,2,0,3,2)$ is the most optimal among the 19 others presented because it offers the lowest AIC value (Figure 3 ).

Based on the test results recorded in Table 7 , the probabilities associated with the various diagnostic tests are all greater than $5 \%$. The null hypothesis is rejected. There is therefore an absence of autocorrelation of errors, homoscedasticity and normality of errors. The model is then specified, stable and validated.

\section{Terminal cointegration test}

Table 8 shows that the F-calculated (3.961271) is higher than the highest value of Pesaran et al. (2001) at the 5\% threshold. Consequently, there is a long-term relationship between the Gross Domestic Product per capita and its determinants in Ivory Coast.
The simple inter-variable correlation matrix (Table 8) shows a relationship between the variable such as trade openness and variables such as agricultural and nonagricultural exports, as the degree of association exceeds 0.50 . The correlation matrix is based on a simple correlation between variables. There is also a likely multicollinearity between agricultural exports and trade openness, between non-agricultural exports and trade openness, and between non-agricultural exports and agricultural exports.

The results of the Toda-Yamamoto causality test presented in Table 9 indicate that there is a unidirectional causal relationship at the $5 \%$ and $10 \%$ threshold for trade openness and agricultural exports respectively.

There is also a unidirectional relationship between Gross Domestic Product and non-agricultural exports. In addition, there is a causal relationship in the TodaYamamoto sense between the dependent variable and the independent variable such as non-agricultural exports at the $5 \%$ threshold. The same is true between variables such as trade openness and non-agricultural exports at the $10 \%$ threshold.

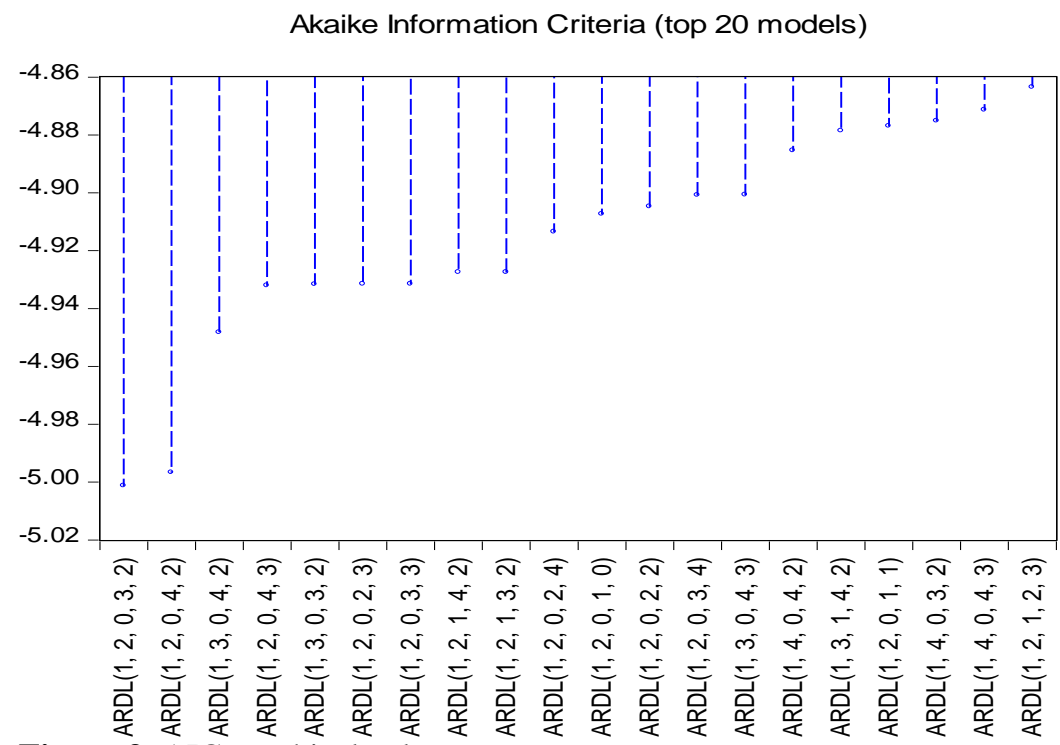

Figure 3: AIC graphical values

Source: Author, estimation using Eviews software.

Table 6: ARDL model diagnostic test results $(1,2,0,3,2)$

\begin{tabular}{llr} 
Test Hypothesis & Tests & Values (Probabilities) \\
\hline Autocorrelation & Breusch-Godfrey & $2.46(0.10)$ \\
Heteroskedasticity & Breusch-Pagan-Godfrey & $1.07(0.43)$ \\
& ARCH & $0.69(0.60)$ \\
Normality & Jarque-Bera & $0.90(0.63)$ \\
Specification & Ramsey (Fisher) & $0.22(0.82)$ \\
\hline
\end{tabular}

Source: Author, estimation using Eviews software.

Table 7: Results of the cointegration test of Pesaran et al. (2001)

\begin{tabular}{lrr}
\hline Variables & \multicolumn{2}{c}{ LGDP, LGFCF, LXA, LXNA, LCO } \\
F-Stat Calculated & 3.961271 & Top terminal \\
Critical threshold & Lower terminal & 4.37 \\
$1 \%$ & 3.29 & 3.49 \\
$5 \%$ & 2.56 & 3.09 \\
\hline
\end{tabular}

Source: Author, estimation using Eviews software. 
Table 8: Simple correlation matrix between variables

\begin{tabular}{lrrrrr}
\hline & LGDP & LGFCF & LCO & LXA & LXNA \\
\hline LGDP & 1.000000 & 0.286781 & -0.778639 & -0.645479 & -0.587134 \\
LGFCF & 0.286781 & 1.000000 & 0.187254 & 0.246528 & 0.412640 \\
LCO & -0.778639 & 0.187254 & 1.000000 & 0.885983 & 0.945356 \\
LXA & -0.645479 & 0.246528 & 0.885983 & 1.000000 & 0.911469 \\
LXNA & -0.587134 & 0.412640 & 0.945356 & 0.911469 & 1.000000 \\
\hline
\end{tabular}

Source: Author, estimation using Eviews software.

Table 9: Results of the causality test in the sense of Toda-Yamamoto

\begin{tabular}{|c|c|c|c|c|c|c|c|}
\hline \multirow[t]{2}{*}{$\mathrm{k}$} & \multirow[t]{2}{*}{$\mathrm{d}_{\max }$} & \multirow{2}{*}{$\begin{array}{c}\text { Dependent } \\
\text { variables }\end{array}$} & \multicolumn{5}{|c|}{ Explanatory or causal variables (probabilities) } \\
\hline & & & LGDP & LGFCF & $\mathrm{LCO}$ & LXA & LXNA \\
\hline \multirow[t]{5}{*}{4} & 1 & LGDP & - & $1.95(0.37)$ & $1.59(0.45)$ & $2.23(0.32)$ & $0.82(0.66)$ \\
\hline & & LGFCF & $4.38(0.11)$ & - & $\begin{array}{r}2.1 \\
(0.23)\end{array}$ & $0.93(0.62)$ & $1.44(0.48)$ \\
\hline & & $\mathrm{LCO}$ & $17.46(0.00)^{*}$ & $1.10(0.57)$ & - & $5.56(0.06)^{* *}$ & $4.02(0.13)$ \\
\hline & & LXA & $0.44(0.79)$ & $0.04(0.97)$ & $0.39(0.82)$ & - & $0.58(0.74)$ \\
\hline & & LXNA & $18.69(0.00)^{*}$ & $1.37(0.50)$ & $4.81(0.08)^{* *}$ & $1.45(0.48)$ & - \\
\hline
\end{tabular}

Note: (.): Probabilities (p-value); *: significant at 5\%; **: significant at 10\%; and values = statistics from $\chi 2$; k: optimal lag of the level VAR (AIC); dmax: maximum order of integration of the variables.

Source: Author, estimation using Eviews software.

\section{Short-term coefficients}

The results of the short-term coefficients summarized in Table 10 show that agricultural exports have positive and significant effects on gross domestic product, although the effect remains small. Thus, when agricultural exports increase by $1 \%$, per capita gross domestic product increases by $0.35 \%$. These results justify the importance of agriculture in the Ivorian economy.

Moreover, there is a positive and significant relationship between Gross Domestic Product and Gross Fixed Capital Formation (Investment) at the 1\% threshold. A $1 \%$ increase in gross fixed capital formation stimulates economic growth by $0.16 \%$.

It is also noted that non-agricultural exports have a positive but not significant effect on Gross Domestic Product.

Finally, trade openness has a negative and statistically insignificant coefficient on gross domestic product. However, when it is lagged by one period, it has a positive and significant impact on gross domestic product. Thus, a $1 \%$ increase in trade openness leads to a $0.25 \%$ increase in GDP. These results could be explained by the fact that the beneficial effects of trade openness fade away very quickly and that there is a deterioration in the terms of trade in most developing countries, which base their exports mainly on primary products.

Table 10: Short-term coefficients

\begin{tabular}{lrr}
\hline Dependent variable: LGDP & \\
Variables & Coefficients & Probability \\
\hline D(LGFCF) & 0.159021 & 0.0000 \\
D(LGFCF(-1)) & -0.075405 & 0.0252 \\
D(LXA) & 0.354193 & 0.0453 \\
D(LXNA) & -0.002608 & 0.9432 \\
D(LXNA(-2)) & -0.039024 & 0.1001 \\
D(LCO) & -0.142109 & 0.0536 \\
D(LCO(-1) & 0.258203 & 0.0162 \\
CointEq(-1) & -0.710249 & 0.0000 \\
\hline
\end{tabular}

Souce: Author, estimation using Eviews software.

\section{Long-term coefficients}

According to Table 11, the sign of the coefficient associated with non-agricultural exports is positive and significant at the $1 \%$ threshold. In the long run, when nonagricultural exports grow by $1 \%$, gross domestic product also increases by $0.16 \%$. This result is in line with that of Tokplonou and Ahodode (2009). These authors found a positive and statistically significant long-term influence of non-agricultural exports on Benin's economic growth. Moreover, they encourage policies to implement an export diversification policy and not to focus exclusively on agricultural commodities.

The correlation between agricultural exports and long-term GDP is positive and significant. A $1 \%$ increase in agricultural exports accelerates economic growth by $0.013 \%$. However, this rate appears to be increasingly weak. This is due to the increasing number of countries exporting the same agricultural commodities such as coffee, cocoa, cotton etc., and the growing number of countries exporting the same agricultural products (Douillet, 2012).

In the long term, trade openness has a significant negative impact on economic growth at the $1 \%$ threshold. A $1 \%$ increase in trade openness leads to a $0.43 \%$ decrease in gross domestic product per capita. This means that trade in its current state negatively affects economic growth. Foreign trade is not a proven source of growth for Ivory Coast in the case of our study. These assertions are similar to those of Zahonogo (2017). Also, other authors such as Agbahoungba and Thiam (2018) have analysed the effects of trade opening in the ECOWAS zone. Indeed, in their respective works, the authors concluded that there is a threshold beyond which international trade negatively affects the economic performance of sub-Saharan African countries.

Finally, the long-term coefficient associated with gross fixed capital formation is positive and statistically significant at the $1 \%$ threshold. The $1 \%$ increase in gross fixed capital formation leads to GDP growth of $0.27 \%$. 
This result justifies the importance of investment in the formation of a nation's wealth (Diagne and Fall, 2007).

Table 11: Estimation results of long-term coefficients Dependent variable: LGDP

\begin{tabular}{lrr} 
Variables & Coefficients & Probability \\
\hline LGFCF & 0.265928 & 0.0000 \\
LXA & 0.012931 & 0.0384 \\
LXNA & 0.162760 & 0.0013 \\
LCO & -0.434059 & 0.0000 \\
C & 11.392978 & 0.0000 \\
\hline
\end{tabular}

Source: Author, estimation using Eviews software.

\section{CONCLUSION}

The main objective of this study is to assess the contribution of agricultural and non-agricultural exports to the economic growth of Ivory Coast between 1985 and 2015.

The results show that agricultural exports have positive and significant effects on the gross domestic product, even if this effect is less in the long term, due to the volatility of agricultural commodity prices. Moreover, gross fixed capital formation (Investment) stimulates economic growth, but its impact is more interesting in the long term. On the other hand, non-agricultural exports have a positive but not significant effect on GDP because of the non-competitiveness of these manufacturing products and because of unfair and disproportionate competition on international markets for finished products. Nevertheless, in the long run, they improve the country's economic performance.

Finally, trade openness, in its current state, negatively affects the economic performance of Ivory Coast, a country exporting primary products. In fact, the beneficial effects of trade opening are fading away very quickly because of the deterioration in the terms of trade.

As a recommendation, the Ivorian government should diversify its export basket in order to minimize the variability of export revenues, reduce the risks of deterioration in the terms of trade and sustain economic growth.

\section{REFERENCES}

AGBAHOUNGBA, W. S. L., \& THIAM, I. (2018). Effets du Commerce Extérieur sur la Croissance économique en Zone CEDEAO. Annales de l'Université de Parakou, Série Sciences Economiques et de Gestion, pp. 72-87. Online at: https://mpra.ub.uni-muenchen.de/89035/

AISA (2010). Programme national d'investissement agricole (2010-2015). Rapport d'expertise de l'Association Ivoirienne des Sciences Agronomiques (AISA), p118. Online at: http://extwprlegs1.fao.org/docs/pdf/IVC176030.pdf.

BALASSA, B. (1978). Exports and economic growth: further evidence. Journal of Development Economics, 5(2), pp181-89. DOI: https://doi.org/10.1016/03043878(78)90006-8

BANQUE MONDIALE (2016). Performances économiques ivoiriennes depuis la fin de la crise postélectorale $\gg \quad 45$. Online at: http://documents.banquemondiale.org/curated/fr/132981 468230123662/pdf/956010FRENCH0W0te0March0201 50Final0.pdf

DIAGNE, Y. S., \& FALL, A. (2007). Impact of public infrastructures on firms' productivity in Senegal, Forecasting and Economic Studies Department, Munich Personal RePEc Archive, p. 44. Online at: https://mpra.ub.uni-

muenchen.de/54809/1/MPRA_paper_54809.pdf

DOUILLET, M. (2012). Trade policies and agriculture in Sub-Saharan Africa Comparative analysis in a Computable General Equilibrium framework. PhD Dissertation. Sciences Po publications info: hdl:2441/45eb019724s

FEDER, G. (1983). On exports and economic growth. Journal of Development Economics, No., 12, pp. 59-73. DOI: https://doi.org/10.1016/0304-3878(83)90031-7 https://doi.org/10.1111/j.1467-8268.2003.00071.x

JLIDI, N. (1996). Les exportations, les importations et la croissance économique, rapport de recherche en vue de l'obtention de la maitrise en sciences économiques, Université de Montréal, p. 113. Dissertation.

JOHANSEN, S. (1991). Estimation and Hypothesis Testing of Cointegration Vectors in Gaussian Vector Autoregressive Models. Econometrica, Vol.59, pp. 15511580. DOI: $\underline{10.2307 / 2938278}$

KOUAKOU, K. P. A. (2017). Analyse De La Performance Productive De L'agriculture Urbaine Dans Le District d'Abidjan. European Scientific Journal, ESJ, 13(35), 288-301.

DOI: https://doi.org/10.19044/esj.2017.v13n35p288

KPEMOUA, P. (2016). Exportations et croissance économique au Togo, p. 28. HAL Id: halshs-01332738 https://halshs.archives-ouvertes.fr/halshs-01332738

MICHAELY, M. (1977). Exports and growth: An empirical investigation. Journal of Development Economics, pp. 49-53. DOI: https://doi.org/10.1016/03043878(77)90006-2

N'ZUÉ, F. (2003). Le Rôle des Exportations dans le Processus de Croissance Economique de la Côte d'Ivoire: Ses implications pour des Stratégies de créations d'Emplois Durables. African Development Review, pp. 199-217. DOI:

PESARAN, M. H., SHIN, Y. \& SMITH, R. J. (2001). Bounds Testing Approaches to the Analysis of Level Relationships, in Journal of Applied Econometrics, Vol.16, No.3, pp. 289-326. DOI: https://doi.org/10.1002/jae.616

TODA, H. Y., \& YAMAMOTO, T. (1995). Statistical Inference in Vector Autoregressions with Possibly Integrated Processes, in Journal of Econometrics, Vol. 66, pp. 225-250. DOI: https://doi.org/10.1016/03044076(94)01616-8

TOKPLONOU, L., \& AHODODÉ, B. (2009). Analyse des effets des exportations non agricoles sur la croissance et le bien-être au Bénin, mémoire de DEA. Université d'Abomey-Calavi, p. 98.

ZAHONOGO, P. (2017). Trade and economic growth in developing countries: Evidence from sub-Saharan Africa. Journal of African Trade (2017), p16. DOI: https://doi.org/10.1016/j.joat.2017.02.001 
ZAMBLE, C. (2015). Impact du changement de politique agricole dans la filière cacao en Côte d'Ivoire : analyse de son évolution, Mémoire de Maîtrise, Université Laval, 92p. Online on: https://corpus.ulaval.ca/jspui/bitstream/20.500.11794/260 39/1/31683.pdf

Appendix 1: Data used in the study

\begin{tabular}{lrrrrr}
\hline PERIODS & \multicolumn{1}{c}{ GDP } & \multicolumn{1}{c}{ GFCF } & \multicolumn{1}{c}{ XA } & \multicolumn{1}{l}{ XNA } & \multicolumn{1}{c}{ CO } \\
\hline 1985 & 1639.95874 & 11.7710855 & 44609 & 1318100 & 8093456.13 \\
1986 & 1629.99567 & 11.8174755 & 34760 & 1160400 & 7399921.37 \\
1987 & 1565.43783 & 11.7696985 & 28199 & 929100 & 6947917.32 \\
1988 & 1527.15612 & 11.4848529 & 22501 & 826500 & 6669285.52 \\
1989 & 1517.06964 & 10.3175226 & 26851 & 895700 & 7232421.17 \\
1990 & 1448.03364 & 8.50214187 & 41609.8 & 793012.4 & 7213622.83 \\
1991 & 1398.22024 & 8.57419991 & 42569.3 & 763073.9 & 7244427.65 \\
1992 & 1346.79807 & 8.50242173 & 43057.9 & 801362.7 & 7901110.75 \\
1993 & 1298.84419 & 9.3454645 & 35135.9 & 713229 & 7539980.24 \\
1994 & 1266.5316 & 11.5492123 & 68908.8 & 1522420 & 9835523.25 \\
1995 & 1314.11994 & 13.6861231 & 96089 & 1819297 & 11080445.7 \\
1996 & 1372.7902 & 14.8080272 & 91554 & 2188326 & 11024398.5 \\
1997 & 1382.62159 & 13.9048381 & 14748 & 2495623 & 12080004.1 \\
1998 & 1410.73839 & 14.3236227 & 183665 & 2592600 & 12130499.2 \\
1999 & 1396.99955 & 13.9981885 & 182488 & 2758513 & 12476198.5 \\
2000 & 1336.42961 & 10.2724728 & 137192 & 2534366 & 12454482.7 \\
2001 & 1310.28647 & 8.64096849 & 221171 & 2669423 & 12533091.8 \\
2002 & 1264.22231 & 10.0705501 & 377130 & 3456184 & 13869536.8 \\
2003 & 1224.96834 & 8.25346592 & 364937 & 3189550 & 13306806.9 \\
2004 & 1218.12035 & 9.34926236 & 296500 & 3655377 & 15227289.9 \\
2005 & 1216.20847 & 9.16693807 & 309520 & 3809246.33 & 17221939.4 \\
2006 & 1210.66821 & 9.78809632 & 319800 & 4206857.08 & 17777502.4 \\
2007 & 1207.08719 & 11.6147757 & 366219 & 3865586.91 & 17070013.6 \\
2008 & 1211.62384 & 10.9386765 & 473900 & 4409963.64 & 17016838.7 \\
2009 & 1223.51062 & 10.8710167 & 532000 & 5077175.36 & 18098079.5 \\
2010 & 1219.7491 & 12.3165364 & 1883039.97 & 5539717.56 & 19168975.2 \\
2011 & 1138.66496 & 8.95112015 & 1967935.29 & 5797514.61 & 19047085.5 \\
2012 & 1229.7782 & 12.1067893 & 1720960.82 & 6041005.82 & 19878196.1 \\
2013 & 1305.70923 & 16.9953189 & 1930508.95 & 7157155.79 & 17600909.4 \\
2014 & 1384.91035 & 18.8791961 & 1102138.89 & 6752676.31 & 14052251.3 \\
2015 & 1469.73018 & 19.5297912 & 931132.75 & 7741831.83 & 14153737.6 \\
\hline & & & & &
\end{tabular}

